\title{
A nyaki ütőerek dissectiója - 19 eset retrospektív elemzése
}

\author{
Forró Csilla dr. ${ }^{1,2}$ - Mészáros Zsófia dr. ${ }^{2}$. Sipos Márton ${ }^{3}$ \\ Kerényi Rita Zsuzsanna dr. ${ }^{4}$. Barsi Péter dr. ${ }^{4}$. Rudas Gábor dr. ${ }^{4}$ \\ Bereczki Dániel dr. ${ }^{2,5}$. Vastagh Ildikó dr. ${ }^{2,6}$

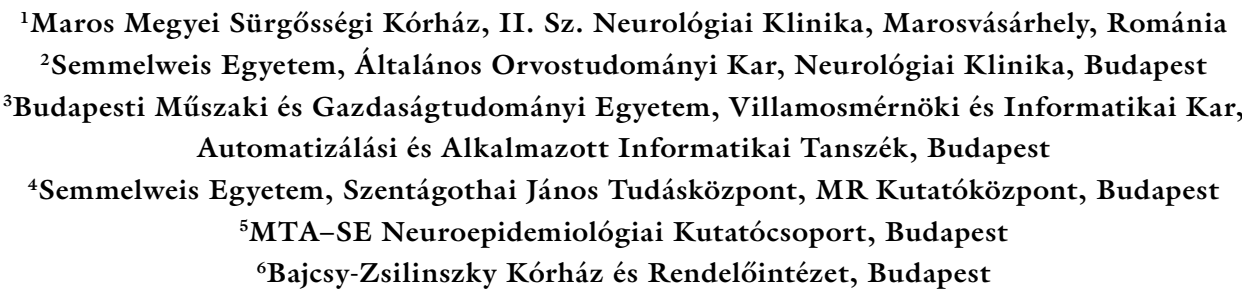

A cervicalis agyi erek dissectiója az ischaemiás stroke-betegség gyakori oka a fiatal felnőttek körében. Kialakulhat erőteljes nyaki trauma, de minor erőbehatás következtében is. Gyakori a spontán esetek előfordulása, melyek genetikai, anatómiai és környezeti tényezőkkel is összefüggésbe hozhatók. A kórkép klinikai megjelenése változatos, a tünetek lehetnek kizárólag helyi jellegüek, illetve az érintett arteriás területre jellemzőek. Korai felismerése kiemelkedően fontos, ugyanis az idejében megkezdett kezeléssel kimenetele számottevően javítható. A végleges diagnózis felállításához a képalkotó eljárások elengedhetetlenek. A közlemény célja a cervicalis agyi erek dissectiójának (carotis és vertebralis arteria dissectio) összefogló leírása 19 eset bemutatása kapcsán. A vizsgálat során három év alatt a Neurológiai Klinikán extracranialis arteria dissectio miatt kezelt betegek klinikai jellemzőit, rizikófaktorait, diagnosztikai eredményeit és terápiáját elemeztük. A kórkép prognózisa változatos, betegeink $42 \%$-a tünetmentessé vált.

Orv Hetil. 2019; 160(22): 861-868.

Kulcsszavak: vertebralis arteria dissectio, arteria carotis interna dissectio, ischaemiás stroke

\section{Cervical artery dissection - retrospective analysis of 19 cases}

Cervical artery dissection is a common cause of stroke in young adults. It might occur shortly after a forceful neck trauma or a minor injury. However, spontaneous dissection is also common, which is associated with genetic, anatomical or environmental risk factors. Cervical artery dissection can produce a broad spectrum of clinical presentation varying from local symptoms to focal neurological deficits determined by the arterial territory involved. Early recognition is important since immediate initiation of treatment can significantly improve patient outcomes. While clinical features may raise suspicion for dissection, the diagnosis has to be confirmed by neuroimaging findings. The purpose of this paper is to give an overview on cervical (carotid and vertebral) artery dissections while presenting 19 cases. During three years, we evaluated the clinical features, risk factors, diagnostic and therapeutic procedures of these patients admitted with extracranial artery dissection. The prognosis of the disease can vary, $42 \%$ of our patients became asymptomatic.

Keywords: vertebral artery dissection, internal carotid artery dissection, ischemic stroke

Forró Cs, Mészáros Zs, Sipos M, Kerényi RZs, Barsi P, Rudas G, Bereczki D, Vastagh I. [Cervical artery dissection - retrospective analysis of 19 cases]. Orv Hetil. 2019; 160(22): 861-868.

(Beérkezett: 2018. október 22.; elfogadva: 2018. december 14.)

\section{Rövidítések}

ACI $=$ arteria carotis interna; $\mathrm{AHA}=($ American Heart Association) Amerikai Szív Egyesület; ASA = (American Stroke Association) Amerikai Stroke Egyesület; AV = arteria vertebralis;
$\mathrm{CAD}=($ cervical artery dissection $)$ cervicalis agyi erek dissectiója; CADISP (Cervical Artery Dissection and Ischemic Stroke Patients) nyaki artéria dissectio és ischaemiás stroke betegek; CADISS $=($ Cervical Artery Dissection in Stroke Study $)$ cercvi- 
calis artériák dissectiója strokeban címú vizsgálat; $\mathrm{CT}=(\mathrm{com}-$ puted tomography) komputertomográfia; CTA $=$ (computed tomography angiography) komputertomográfiás angiográfia; DSA = digitális szubtrakciós angiográfia; INR = (international normalized ratio) nemzetközi normalizált ráta; iv. = intravénás; LMWH $=$ (low molecular weight heparin $)$ alacsony molekulasúlyú heparin; MRA = (magnetic resonance angiography) mágnesesrezonancia-angiográfia; $\mathrm{MRI}=$ (magnetic resonance imaging) mágnesesrezonancia-képalkotás; $\mathrm{mRS}=$ módosított Rankin-skála; rtPA = (recombinant tissue plasminogen activator) rekombináns szöveti plazminogén aktivátor; TIA = (transient ischemic attack) átmeneti ischaemiás attak

A cervicalis agyi erek dissectiója $(\mathrm{CAD})$ a stroke-betegség gyakori etiológiája fiatalkorban; az 50 év alatti ischaemiás stroke-os esetek körülbelül 20\%-át képezi, azonban bármely életkorban előfordulhat. Az epidemiológiai vizsgálatok szerint a CAD miatt gondozott betegek átlagéletkora 45 év, a nemi megoszlás enyhe férfidominanciát mutat (53-57\%). A CAD incidenciája az átlaglakosságban alacsony: 2,6/100 000 lakos [1]. A tényleges incidencia a nem diagnosztizált, szegényes tünetegyüttessel jelentkező esetek miatt valószínúleg nagyobb [2].

A kórkép kialakulhat akár minor erôbehatás, tompa nyaki trauma következtében, de gyakori a spontán esetek száma is, melyek genetikai, anatómiai és környezeti tényezőkkel hozhatók összefüggésbe [3]. A hagyományos cardiovascularis rizikófaktorok nem teljesen bizonyított szerepe mellett a legújabb vizsgálatok környezeti tényezőkként az infekciók független szerepét is igazolták, ami részben magyarázhatja a CAD magasabb ôszi, téli előfordulását. Egyes szerző́k a minor traumákat is környezeti tényező́kként tartják számon [2]. Feltételezhető, hogy az érfalbetegségek, valamint az örökletes kötőszöveti betegségek - mint az Erdheim-Gsell-szindróma (cysticus media necrosis), a pseudoxanthoma elasticum, az Ehlers-Danlos-szindróma, a Marfan-szindróma, az osteogenesis imperfecta, a fibromuscularis dysplasia - fokozhatják a nyaki erek dissectiójának rizikóját $[2,3]$.

Dissectio során a vasa vasorum vagy az érintima folytonossága megszakad, a keringő vér a repedésen keresztül ki-, illetve beáramlik az arteria falát alkotó rétegek közé, melyek szétválása egy járulékos csatorna (állumen) kialakulását idézi elő az ér falában. A vér beáramlása intramuralis haematoma kialakulásához vezet, mely terjedhet az adventitia irányába, ekkor pseudoaneurysma alakulhat ki. Az intramuralis haematoma elemelheti az intimát, és az ér valódi belső lumenének szúkülletét, végső esetben occlusióját okozhatja (1.ábra) $[2,4]$. A haematoma vagy a pseudoaneurysma kompressziós hatást is gyakorolhat a környező szövetekre, Horner-szindrómához vezethet (ptosis, miosis, ritkán anhydrosissal társultan) [5].

$\mathrm{Az}$ irodalmi adatok alapján a betegek $58-78 \%$-ában ischaemiás stroke alakul ki, amely kétféle patomechanizmussal jöhet létre. A disszekálódott arterián kialakult stenosis vagy occlusio hemodinamikai elégtelenség következtében határterületi infarktust okozhat. Az állumenben

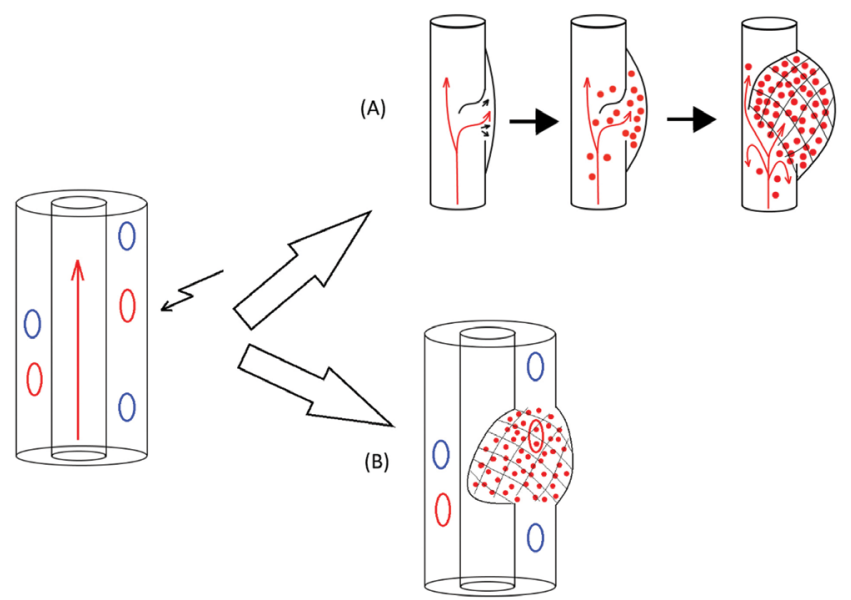

1. ábra

A) Az érintima folytonosságának megszakadása következtében a vér a repedésen keresztül az arteria falát alkotó rétegek közé áramlik, állumen kialakulását okozva. Az állumenben keletkező thrombus vagy ennek darabkái továbbsodródhatnak, és így arterioarteriás emboliát okozhatnak. B) A vasa vasorum (az érfalban látható ovális ellipszisek; piros ellipszis - arteria, kék ellipszis vena) sérülése során az ér falában haematoma alakul ki, mely az ér valódi belső lumenének stenosisához/occlusiójához vezethet

keletkező thrombus vagy ennek részei továbbsodródva, arterioarteriás embolisatio következtében okozhatnak ischaemiás stroke-ot. Az arterioarteriás embolisatiós mechanizmus előfordulását gyakoribbnak találták $[6,7]$.

A CAD klinikai tünetei változatosak, a tünetek jellege, súlyossága jelentősen eltérő lehet. CAD esetén a betegek akár teljesen vagy hosszabb ideig is tünetmentesek lehetnek $[4,6]$. A tipikus arteria vertebralis (AV) dissectio tünetegyüttesének a halántéktáji fejfájást, a nyak hátsó részére lokalizálódó fájdalmat, a hátsó agyi keringészavar következtében kialakuló tüneteket tartjuk. Az arteria carotis interna (ACI) dissectiójára az ipsilateralis fejfájás vagy nyakfájás, a Horner-szindróma, a retina- vagy cerebralis ischaemia tünetei jellemzők [8].

Amennyiben a klinikai gyanú fennáll, a képalkotó diagnosztikai módszerek elengedhetetlenek a dissectio diagnózisának felállításához. Korábban a hagyományos digitális szubtrakciós angiográfia (DSA) volt a dissectiodiagnosztika „gold standarja”. A DSA korlátai, illetve lehetséges iatrogén szövődményei miatt azonban háttérbe szorult a noninvazív képalkotó eljárások (carotis-vertebralis duplex szonográfia, CT és CT-angiográfia, MR és MR-angiográfia) fejlődésének köszönhetően $[4,9]$.

A CAD az esetek nagy részében a megfelelő kezelés mellett kedvező prognózisú betegség. A nemzetközi stroke-adatbázisok adatai alapján a CAD-os esetek 70\%ában alakul ki kisebb-nagyobb mértékú ischaemiás agyi károsodás. A kezelés két szakaszra osztható: az akut szakaszban az életveszély elhárítására, az ischaemiás stroke megelőzésére, valamint a még csak funkcionálisan károsodott agyszövet (penumbra) megmentésére kell irányulnia. A későbbiekben a további ischaemia kialakulásának, illetve a stroke ismétlődésének megelőzése a cél $[2,5]$.

Közleményünkben a klinikánkon végzett retrospektív vizsgálat során három év alatt 19, extracranialis arteria 
dissectio miatt kezelt beteg klinikai jellemzőit, rizikófaktorait, diagnosztikai eredményeit, terápiáját, valamint a betegség kórlefolyását elemeztük.

\section{Módszer}

Retrospektív esettanulmányt végeztünk, amelynek során a Semmelweis Egyetem Neurológiai Klinikáján 2015. január 1-je és 2017. december 31-e között az agyi ütőerek nem rupturált dissectiója miatt (BNO-kód: I67.00) kezelt betegek adatait elemeztük. A három év alatt 2192 beteget kezeltünk ischaemiás stroke miatt. A panaszok és a fizikális vizsgálat alapján merült fel a CAD diagnózisa, amelyet képalkotó vizsgálat követett. Az első diagnosztikai lépés a leggyakrabban a carotis-vertebralis duplex ultrahangvizsgálat volt, ezt követően megerősítő képalkotó vizsgálat történt (CTA/MRA). Az ischaemiás károsodást agyi CT- vagy MR-vizsgálat igazolta.

Részletesen elemeztük a betegek befolyásolható és nem befolyásolható cardiovascularis rizikótényezőit, a CAD egyes kiváltó tényezőit, klinikai megjelenési formáit, az alkalmazott diagnosztikai és terápiás eljárásokat, valamint a betegség kórlefolyását. Genetikai vizsgálatok betegeinknél nem történtek.

Célkitűzésünk saját eseteink jellemzőinek összevetése volt az irodalmi adatokkal.

\section{Eredmények}

A három év alatt 19 betegnél diagnosztizáltunk CAD-ot, ebből 13 esetben az AV, valamint 6 betegben az ACI volt érintett. A vizsgált populációban a nemek szerinti eloszlás női dominanciát mutatott (11 nő és 8 férfi), az átlagéletkor $43 \pm 13$ év volt.

\section{Rizikó-, illetve kiváltó tényezốk}

Az 1. táblázat összefoglalja a betegek klasszikus cardiovascularis rizikófaktorait és az úgynevezett nem klasszikus dissectióra hajlamosító tényezőket. A 2. táblázat a dissectiót kiváltó tényezőket szemlélteti. Korábbi ischaemiás stroke egy beteg anamnézisében fordult elö; a dissectio lehetősége már akkor felmerült, ezt azonban a képalkotó vizsgálatok nem támasztották alá, ismételt felvétele az ellenoldali arteria carotis interna dissectiója miatt történt.

\section{Klinikai tünetek}

13 beteg panaszolt fejájást, 10 nyakfájást, 1 tinnitust. Neurológiai kórjeleket 14 betegnél találtunk (somnolentia 1 , homonym hemianopia 2 , tekintési paresis 1 , centralis facialis paresis 3 , felső végtagi paresis 1 , hemiparesis 7 , érzészavar 7 , aphasia 1 , vertigo 6 , nystagmus 5 , dysmetria 3 , járási ataxia 2 , dysarthria 2 , dysphagia 1 betegben). A neurológiai tünetek 2 betegnél átmenetiek voltak. Két betegben fordult elő bilateralis ACI-dissectio.
1. táblázat $\mid$ A cervicalis nyaki erek dissectiójának rizikótényezői a vizsgált populációban $[\mathrm{n}(\%)]$

\begin{tabular}{lc}
\hline Klasszikus vascularis rizikótényezők & \\
\hline Dohányzás & $5(26 \%)$ \\
Alkoholfogyasztás & $8(42 \%)$ \\
Magas vérnyomás & $8(42 \%)$ \\
Dyslipidaemia & $11(58 \%)$ \\
Cukorbetegség & $2(11 \%)$ \\
Elhízás & $0(0 \%)$ \\
\hline
\end{tabular}

\begin{tabular}{ll}
\hline Nem klasszikus vascularis rizikótényezők & \\
\hline Migrén & $3(16 \%)$ \\
Ophthalmicus migrén & $0(0 \%)$ \\
Örökletes kötőszöveti betegségek & $0(0 \%)$ \\
Hyperhomocysteinaemia & $0(0 \%)$ \\
ACI kinking/coiling (ACI-dissectiós eseteink 50\%-a) & $3(16 \%)$ \\
Orális fogamzásgátlót használó nők (a nőbetegek 27\%-a) & $3(16 \%)$ \\
Terhesség és post partum időszak & $0(0 \%)$ \\
\hline
\end{tabular}

2. táblázat $\mid$ A cervicalis nyaki erek dissectiójának kiváltó tényezői a vizsgált populációban [n (\%)]

\begin{tabular}{ll}
\hline Kiváltó tényezők & \\
\hline Minor trauma & $6(31 \%)$ \\
Autóbaleset & $2(11 \%)$ \\
Sportolás & $2(11 \%)$ \\
Táncolás & $1(5 \%)$ \\
Fertőzéses betegség & $3(16 \%)$ \\
Cannabishasználat & $1(5 \%)$ \\
\hline
\end{tabular}

Közülük az egyik betegnek autóbaleset következtében alakult ki jobb oldali centralis facialis paresise, jobb oldali súlyos fokú hemiparesise és globalis aphasiája, melyeket az autóbaleset során elszenvedett kis kiterjedésű, a bal oldali prefrontális lebenyt érintő contusio nem magyarázott. A másik autóbaleset egyoldali ACI-dissectiót okozott. A kétoldali ACI-dissectiós betegek közül a másodiknak a tünetei felső légúti fertőzéshez társuló száraz köhögés következtében alakultak ki, és átmenetiek voltak (enyhe fokú jobb oldali hemiparesis és bal oldali amaurosis fugax); agyi MR-vizsgálattal diffúziógátlás nem volt, ezek alapján TIA-t véleményeztünk. Bilateralis AVdissectiót találtunk egy betegnél, akinek fokális neurológiai tünetei nem voltak, és két hete fennálló, szúró jellegű nyaki fájdalom után jelentkezett klinikánkon. A fizikális vizsgálat során a bal AV felett zörejt hallottunk.

\section{Képalkotó vizsgálatok}

Klinikai gyanú esetén képalkotó vizsgálatokkal igazoltuk a diagnózist. 15 betegnél készült nyakiér-duplexultra- 
hangvizsgálat, mely azonban csak 9 betegnél vetette fel a dissectio lehetőségét. 4 betegnél nem történt ultrahangvizsgálat, közülük 2 betegben MRA, a másik 2 betegben pedig CTA alapján diagnosztizáltuk a dissectiót. Minden betegnél, akinél neuroszonológiai vizsgálat volt az első diagnosztikai lépés, további megerősítő képalkotó vizsgálat is történt; 8 betegnél mindhárom képalkotó vizsgálat megtörtént. Minden esetben, ahol az ultrahang nem igazolt kóros elváltozást, az AV volt érintett. A 2-5. ábrák a képalkotó vizsgálatokkal igazolt típusos elváltozásokat mutatják be.

Az agyi parenchyma értékelésére minden esetben CTvagy MR-vizsgálatokat végeztünk. Képalkotó vizsgálattal igazolt ischaemiás laesio 10 betegnél igazolódott (53\%). A három év alatt 2192 beteget kezeltünk ischaemiás stroke miatt, közülük 10 esetben a stroke CAD következtében alakult ki (3 ACI-dissectio, illetve 7 AV-dissectiós esetben). Ezek alapján az összes akut ischaemiás stroke-os esetre vonatkoztatva 0,45\%-ban igazolódott dissectio. 9 betegnél a képalkotó vizsgálat nem igazolt ischaemiás laesiót.

\section{Terápia}

Akut ischaemiás stroke miatt 4 beteg részesült rekanalizációs kezelésben. Szisztémás thrombolysist (iv. rtPA intravénás rekombináns szöveti plazminogén aktivátor alkalmazásával) végeztünk 3 betegnél, mindhárom esetben javultak a tüneteik (a módosított Rankin-skálán [mRS] 1-2-es fokozat). Thrombectomia az autóbaleset következtében kialakult bilateralis carotis dissectiós betegnél történt, akinél a tünetképző bal oldali ACI-dissectio és következményesen distalisan kialakult arteria cerebri media occlusio miatt végezték el az intervenciós beavatkozást. A tünetkezdet és a teljes rekanalizáció között 4 óra telt el, ennek ellenére a beteg tünetei csak enyhén javultak (mRS: 4-es fokozat), nagy kiterjedésű arteria cerebri media területi infarktus alakult ki. A jobb oldali ACI-dissectio áramlászavart, illetve tüneteket nem okozott. A betegek 21\%-a $(\mathrm{n}=4)$ kapott kórházi ellátása alatt preventív dózisú alacsony molekulasúlyú heparint (LMWH).

Szekunder prevencióként minden beteg 3-6 hónapig antithromboticus kezelésben részesült, 8 betegnél aszpirin- vagy klopidogrélmonoterápiát, 1 betegnél kettős thrombocytaaggregáció-gátló kezelést, 10 betegnél orális antikoaguláns terápiát alkalmaztunk (warfarint vagy acenokumarolt, célérték INR 2-3 között).

\section{Kórlefolyás}

A betegség lefolyása a legtöbb esetben kedvező volt: 8 beteg tünetmentesen, 4 jelentős korlátozottság nélkül, 2 csekély korlátozottsággal, 3 mérsékelt rokkantsággal otthonába, illetve rehabilitációs osztályra távozott (mRS: 0-3-as fokozat). Csak az autóbaleset során kialakult két dissectiós esetben jelentkeztek mérsékelten súlyos rokkantságot okozó tünetek (mRS: 4-es fokozat). Haláleset nem történt.
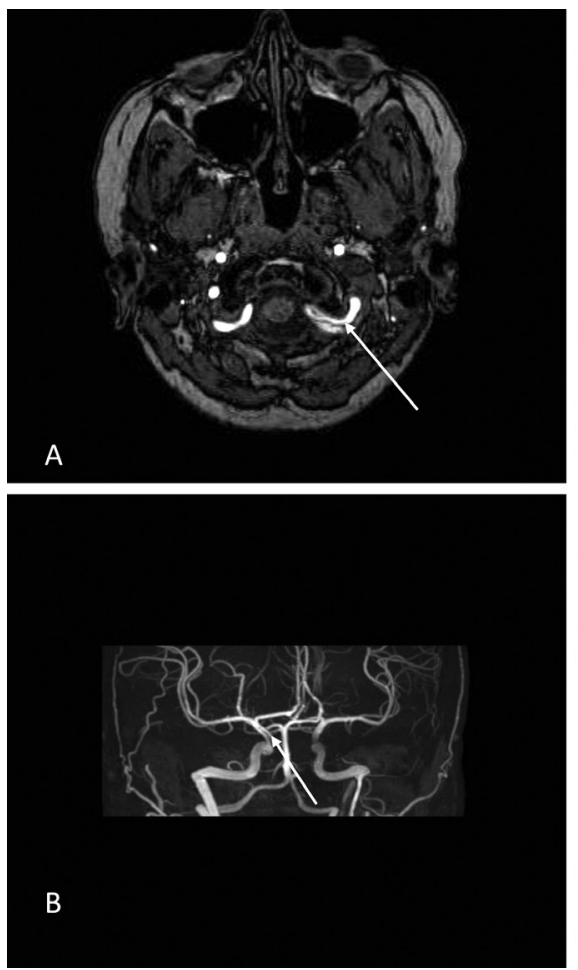
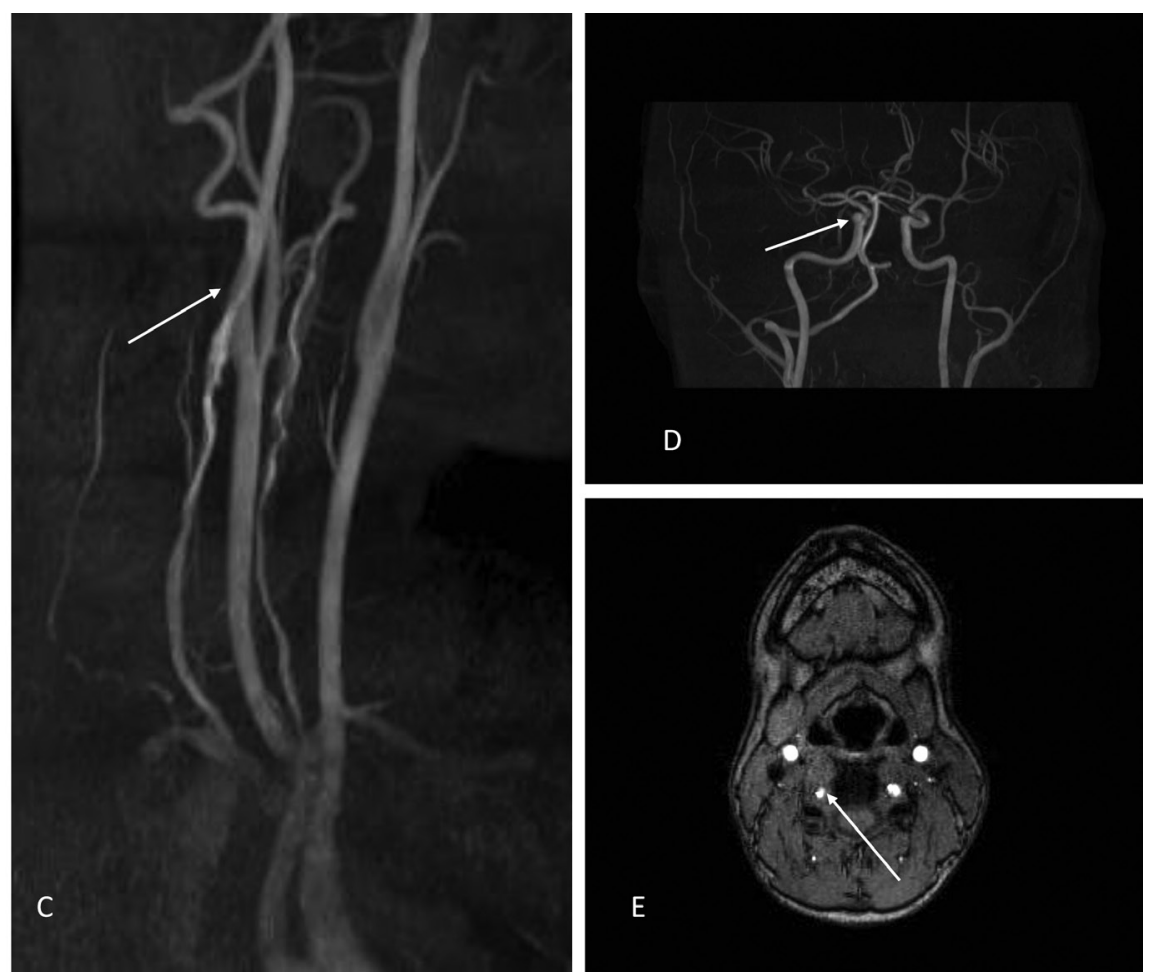

2. ábra

3D TOF MRA mérések láthatók (Philips Ingenia 3T): Az $A$ képen (axialis síkú munkakép) intramuralis haematoma a bal oldali AV területén. A $B$ képen (MIP-kép): intramuralis haematoma a bal oldali ACI területén. C (MIP-kép) és $E$ (axialis munkakép): a jobb oldali AV kettős lumen. $D$ (MIP-kép) pseudoaneurysma 

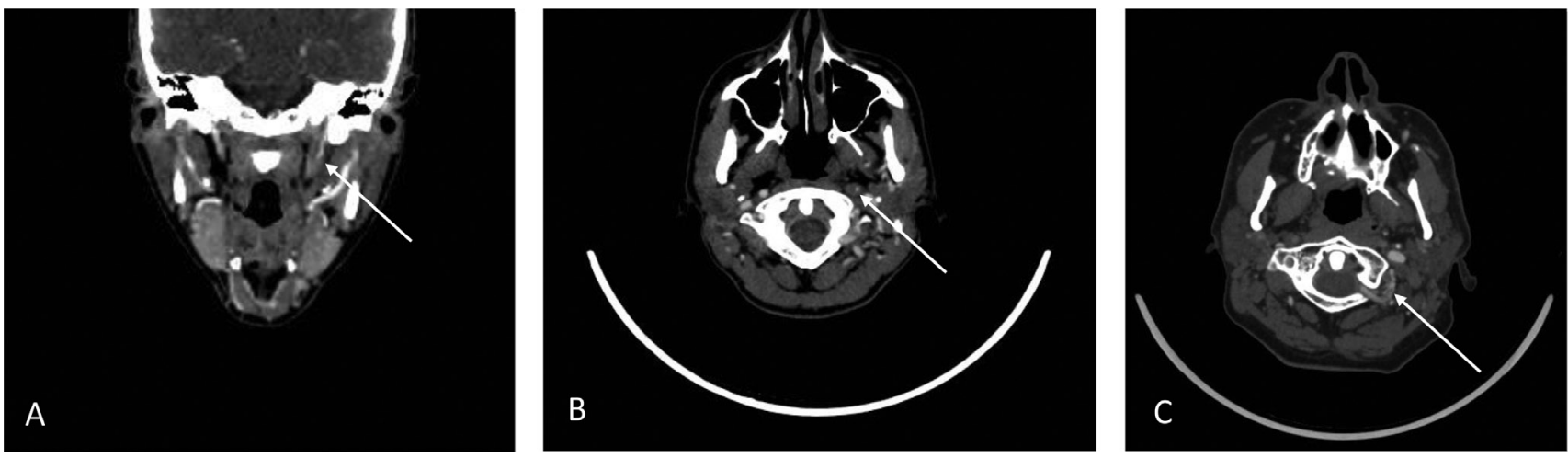

3. ábra

CTA-felvételek artériás fázisban, a nyilak az elváltozásokra mutatnak. $A$ (coronalis síkú) és $B$ (axialis síkú) képen bal oldali ACI dissectiója ábrázolódik, míg az egyik lumenben a kontrasztanyag megjelent, a másik lumennek megfelelően telődéskiesés látható. $C$ (axialis síkú) képen a bal oldali AV dissectiójára és annak lumenét részben kitöltő thrombusra mutat a nyíl

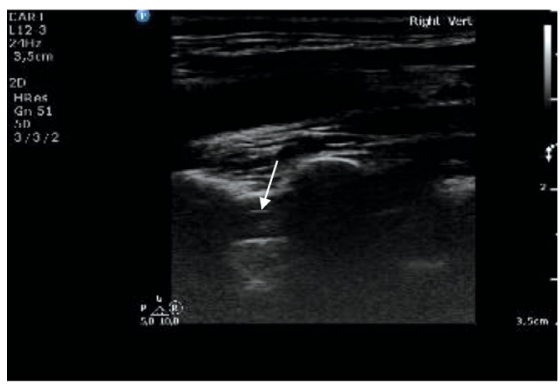

A

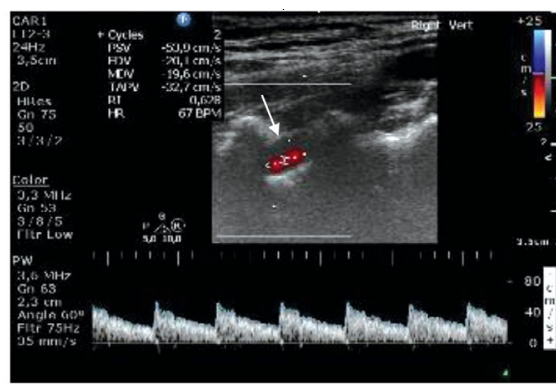

B

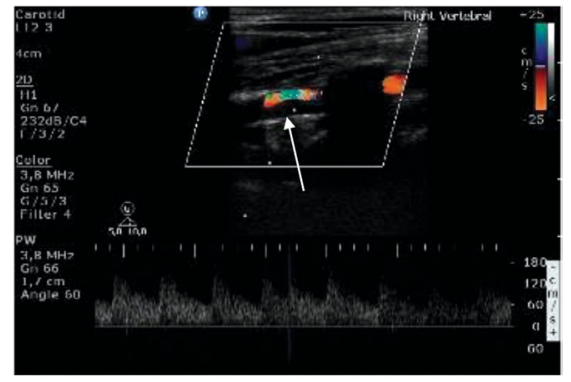

C

4. ábra $\quad$ Az ultrahangos képek az arteria vertebralis dissectio pathognomicus eltéréseit szemléltetik. Mindhárom hosszmetszeti kép a V2 szakaszról készült. $A$ kép: a B-módú felvételen az intima flap látható (fehér nyíl). $B$ kép: a vastag fehér nyíl az AV transzducerhez közeli falára mutat. A color-módban készült képen a residualis lumenben a piros szín laminaris áramlást jelez. A vastag nyíl és a residualis lumen közötti hypoechogen terület intramuralis haematomára utal. $C$ kép: a residualis lumenben az áramlás zöld-sárga-piros színben ábrázolódik, ami turbulens áramlásra utal. Az áramlási sebesség gyorsulása a Doppler-görbén látszik. A fehér nyíl az AV transzducertól távoli falára mutat. A residualis lumen alatti hypoechogen terület intramuralis haematomának felel meg. A képek Philips HD 15, L12-5, lineáris transzducerrel készültek (saját anyag)
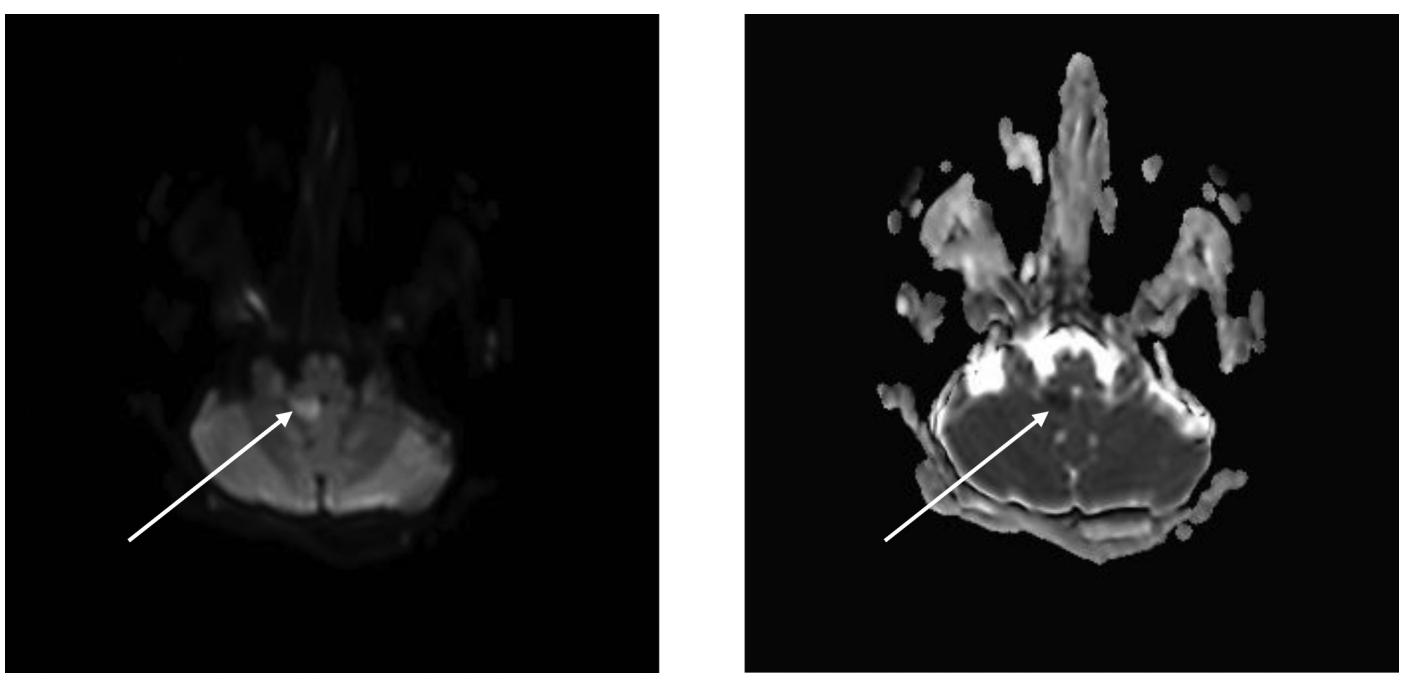

5. ábra

Acut infarctus jobb oldalon a pontocerebellaris régióban (Philips Ingenia 3T, DWI/ADC mérés, axialis síkú), melyet a jobb oldali AV dissectiója okozott. A nyilak a diffúziógátolt területre mutatnak

\section{Megbeszélés}

A dohányzás, a magasvérnyomás-betegség, a dyslipidaemia, a cukorbetegség és az elhízás fontos cardiovascularis rizikófaktorok, növelik az ischaemiás stroke, a myocardi- alis infarctus, illetve a perifériás érbetegség incidenciáját $[10,11]$. A CAD előfordulására való hatásuk nem teljesen tisztázott. A CADISP- (Cervical Artery Dissection and Ischemic Stroke Patients) vizsgálat, melybe 2004 és 2009 között 20 központ betegeit vonták be (690 CAD- 
os beteg, kor és nem alapján illesztett 556, nem CAD következtében kialakult ischaemiás stroke miatt gondozott beteg, valamint 1170 beteget tartalmazó kontrollcsoport) az eddigi legnagyobb CAD-os betegpopulációt vizsgáló tanulmány volt. Eredményei alapján a CAD miatt gondozott betegek között szignifikánsan nagyobb arányban fordult elő hypertonia. A dyslipidaemia, valamint az elhízás előfordulása kisebb volt, attól függetlenül, hogy az ACI vagy az AV volt-e érintett, illetve hogy társult-e a dissectio agyi ischaemiával. Összességében a vascularis rizikófaktorok kisebb arányban fordultak elő a CAD-os betegek körében, mint a nem CAD miatt kialakult ischaemiás stroke-os betegeknél. A nem CAD miatt kialakult ischaemiás stroke-os betegek viszont gyakrabban voltak magas vérnyomásosak, cukorbetegek vagy dohányosok, mint a kontrollcsoport tagjai [11]. Betegeink között szintén gyakori volt a magas vérnyomás, ami korrelál a CADISP, illetve két korábban végzett vizsgálat eredményével. Ennek ellenére két másik, szintén korábban végzett vizsgálat nem igazolt szignifikáns összefüggést $[12,13]$.

Dyslipidaemia: saját betegeinknél az irodalmi adatoktól eltéróen meglepően nagy számban találtunk $(n=11)$ normáltartomány feletti vérzsírértékeket. Ugyanakkor egy, a klinikánkon fiatal életkorban bekövetkező ischaemiás stroke etiológiájának és rizikófaktorainak jellemzőit vizsgáló tanulmány eredményei alapján az egészséges egyénekhez viszonyítva szignifikánsan magasabb arányban fordul elő dyslipidaemia ebben a csoportban, így a dyslipidaemia nem tekinthető független rizikófaktornak a dissectio kialakulásában $[11,14]$. Az irodalmi adatoknak megfelelően $[11,15]$ betegeinknél sem volt jellemző az elhízás, a dohányzás és a cukorbetegség (1. táblázat). A kisebb testtömegindexű egyének a zsírszövet mechanikus védőhatásának hiányában hajlamosabbak lehetnek minor cervicalis trauma által okozott érfalkárosodásra [11].

A korábbi megfigyelések, melyek szerint CAD gyakrabban társul strukturális vagy funkcionális arteria-rendellenességekkel, arra a következtetésre vezettek, hogy a CAD-os betegeknek alkati arteriafal-gyengeségük lehet, melynek bizonyos kiváltó tényezőkkel való társulása (minor nyaki trauma, fertőzés) vezet a kórkép kialakulásához. Önmagában nem jellemző, hogy egy minor eróbehatás, sportolás vagy - egyik betegünknél - elhúzódó köhögés dissectióhoz vezessen [15]. Völker és mtsai 2011-ben a spontán CAD-os, illetve a major trauma során kialakult dissectiós esetek között az arteria falában biopsziás eljárásokkal strukturális különbségeket igazoltak az extracellularis matrix morfológiájában, ismert kötőszöveti betegség hiányában is $[2,16]$. További összefüggés feltételezhető az arteria carotis interna kinking vagy coiling és az ACI-dissectio között [5]. Ezek a morfológiai eltérések ACI-dissectiós betegeink 50\%-ában fordultak elő.

Az irodalmi adatok megemlítik az örökletes kötőszöveti betegségeket, a migrént, a terhességet, a post par- tum periódust, az orális fogamzásgátló, illetve drog használatát is mint a CAD rizikótényezőit. Tanulmányunkban ezek körül csak az orális fogamzásgátló használata volt gyakori, ezeket azonban mindenképp szem előtt kell tartani $[3,5]$.

A neurológiai kép gyakran nem, illetve csak a helyi kísérő tünetek társulása révén különbözik az egyéb eredetű agyi keringészavarokban jelentkező tünetektől. A lokális tünetek feltételezhetően az intramuralis haematoma és a pseudoaneurysma kompressziója következtében alakulnak ki. Ilyenek például a tinnitus, a szokatlan fej-, illetve nyakfájás [1]. Ezeket betegeinkben is gyakran észleltük, 5 betegnél izoláltan, társuló neurológiai góctünetek nélkül. Arnold és mtsai tanulmányozták a kizárólag helyi tünetekkel jelentkező CAD jellegzetességeit. Következtetéseik megfelelnek a betegeink által leírt jellemzőknek, melyek alapján a fájdalom általában elhúzódó, állandó jellegü, a fejájás intenzitása általában erős, a nyakfájás viszont közepes intenzitású és szorító jellegű volt [8].

A CAD-os betegek tünetmentesek is lehetnek, illetve hosszabb idő eltelhet (akár egy hónap) a helyi tünetek és a következményes cerebralis hipoperfúzió miatt kialakuló neurológiai góctünetek megjelenése között, ami a diagnózis felállítását nehezítheti [5].

A carotis-vertebralis duplex szonográfia könnyen hozzáférhető vizsgálati eljárás, klinikai gyanú esetén vagy terápiamonitorizálás céljából biztonságosan alkalmazható, ugyanakkor nem megbízható a diagnózis kizárására, fóként a mandibula síkja felett, a koponyaalap közelében kezdődő vagy intracranialisan terjedő dissectiók esetében [17]. Szenzitivitása a CAD kimutatására 68-95\% az irodalmi adatok szerint, betegeink körében csak 63\%-ban vetette fel a dissectio lehetőségét [18]. Egy 2009-ben publikált tanulmány alapján a CT és a CT-angiográfia, valamint az MR és az MR-angiográfia egymáshoz hasonló szenzitivitással (97-100\%) és specificitással rendelkezik a CAD diagnosztikájában, azonban az Amerikai Stroke Társaság az MR-, MRA-vizsgálatokat ajánlja a választandó képalkotó eljárásoknak dissectio gyanúja esetén $[19,20]$. Ha noninvazív módszerekkel a diagnózis felállítható, nincs szükség DSA végzésére, ellenkező esetben elvégzése indokolt [5]. Betegeinknél diagnosztikus DSA nem történt, a thrombectomián átesett betegnél a kezelés alatt történt DSA is.

A CAD kezelésének elsősorban az ischaemiás stroke kialakulásának, illetve az agyszövet elhalásának megelőzésére kell irányulnia. Annak ellenére, hogy CAD következtében kialakult akut ischaemiás stroke miatt elvégzett szisztémás thrombolysis eredményességére vonatkozó randomizált vizsgálat nem történt, ezeket az eseteket minden, a thrombolysist kiértékelő randomizált klinikai vizsgálat magában foglalta [21, 22]. Feltételezhető, hogy a trombolitikumok hatására az intramuralis thrombus feldarabolódhat, megnövelve az érfalban a nyomást, és ez a dissectio továbbterjedését okozhatja. Ugyanakkor javíthatják az agyi vérátáramlást az occlusiót okozó thrombus méretének csökkentése által [5]. Az elmúlt 10 
évben több, nem randomizált vizsgálatot, illetve metaanalízist végeztek $[7,23]$, melyek bizonyították az intravénás, illetve intraarteriás thrombolysis biztonságosságát is a CAD következményeként kialakuló ischaemiás stroke kezelésében. Következésképpen a jelenlegi irodalmi adatokra hivatkozva a 2018-as AHA/ASA (American Heart Association/American Stroke Association) irányelvek ezen esetekben az intravénás thrombolysis elvégzését javasolják (IIa osztályú ajánlás) [24].

A legtöbb esetben az érfal átlagosan 3 hónap alatt spontán módon meggyógyul. A statisztikák szerint dissectio által okozott occlusio esetében gyakrabban fordul elő spontán rekanalizáció, mint embolisatiónál $[5,25]$. Ebben az idószakban a cél az ischaemiás stroke megelözése antikoaguláns vagy thrombocytaaggregáció-gátló kezelés segítségével [5, 17]. 2015-ben közölték a két antithromboticus terápiát egymással összehasonlító első, 250 beteget vizsgáló randomizált kontrollált CADISStanulmány (Cervical Artery Dissection in Stroke Study) eredményeit, melyek alapján nincs szignifikáns különbség a két csoport között az ipsilateralis ischaemiás stroke, illetve a halálozás kialakulásának megelőzésében. Ezek alapján a 2018-as AHA/ASA irányelvek szekunder prevencióként 3-6 hónapig tartó antikoaguláns vagy antiaggregáns terápiát javasolnak [24]. A CADISS-vizsgálatban az új típusú orális antikoagulánsokat nem vizsgálták, de népszerúségükre való tekintettel a jövőben észszerü lenne hatásosságuk vizsgálata ebben a célcsoportban is [5].

A sebészi terápiákra vonatkozó adatok korlátozottak, angioplasztikát vagy sztentbeültetést az ACI-dissectiók esetében az AHA/ASA csak eredménytelen gyógyszeres terápia után javasol [24].

A CAD összességében jó prognózisú betegség [26], a legtöbb beteg 3-12 hónap alatt meggyógyul. A CADISS-vizsgálatba besorolt betegek 2\%-ánál ismétlődött a stroke a dissectiót követő 3 hónapban [7]. Saját betegeinkben rekurrens CAD nem fordult elő.

\section{Következtetés}

A cervicalis agyi erek dissectiója a stroke viszonylag ritka etiológiája, jellemzően fiatal felnőttekben alakul ki. Korai felismerése kiemelkedően fontos, ugyanis az idejében megkezdett kezeléssel a kimenetele számottevően javítható.

Minden új keletű nyak- és fejfájás esetén gondolni kell a CAD-ra, attól függetlenül, hogy társul-e akut ischaemiás stroke és/vagy TIA tüneteivel.

A CAD diagnózisa képalkotó vizsgálatok alapján történik; a nyakiér-duplexszonográfia nem megbízható a diagnózis kizárásához, ezért klinikai gyanú esetén minden esetben CT-, CTA- vagy MR-, MRA-vizsgálatok szükségesek. A hagyományos DSA-vizsgálat a legtöbb esetben nem szükséges.

Akut ischaemiás stroke tünetei esetén szisztémás thrombolysis, illetve endovascularis beavatkozás elvégzé- se indokolt az erre alkalmas betegeknél. Szekunder prevencióként további 3-6 hónapig orális antikoaguláns vagy antiaggregáns terápia alkalmazandó.

A kórkép prognózisa összességében jó, a csak helyi tünetekkel jelentkező esetekben még kedvezőbb kimenetelre számíthatunk.

Anyagi támogatás: A cikkhez kapcsolódó kutatómunkához a következő anyagi támogatások járultak hozzá: Forró Csilla a Domus Hungarica Junior Ösztöndíjban részesült, egyeztetve a Neurológiai Klinikával, a Szentágothai János Tudásközponttal.

Szerzői munkamegosztás: F. Cs.: Az adatok gyüjtése, feldolgozása, elemzése és összehasonlítása az irodalmi adatokkal, a kézirat megírása és szerkesztése. M. Zs.: Az adatok feldolgozása, az ábrák szerkesztése. S. M.: Az adatok feldolgozása és elemzése, részvétel a kézirat szerkesztésében és kritikus véleményezésében. K. R. Zs.: A képalkotó vizsgálatok eredményeinek leletezése, összegyưjtése, elemzése, feldolgozása, a képanyag elkészítése. B. P.. A képalkotó vizsgálatok feldolgozása, értékelése, a kézirat és a képanyag kritikus véleményezése. R. G.: A képalkotó vizsgálatok összegyưjitése, feldolgozása. B. D.: Az adatok gyújtésének irányítása, feldolgozása, elemzése, a kézirat lektorálása. V. I.: Irányítás az adatok gyưjtésében, feldolgozásában, elemzésében, az ultrahangvizsgálatok elvégzése, tanácsok a kézirat megírásához. A cikk végleges változatát valamennyi szerző elolvasta és jóváhagyta.

Érdekeltségek: A szerzőknek nincsenek érdekeltségeik.

\section{Irodalom}

[1] Debette S, Leys D. Cervical-artery dissections: predisposing factors, diagnosis, and outcome. Lancet Neurol. 2009; 8: 668-678.

[2] Blum CA, Yaghi S. Cervical artery dissection: a review of the epidemiology, pathophysiology, treatment and outcome. Arch Neurosci. 2015; 2: e26670.

[3] Brandt T, Grond-Ginsbach C. Spontaneous cervical artery dissection: from risk factors towards pathogenesis. Stroke 2002; 33 : 657-658.

[4] Robertson JJ, Koyfman A. Cervical artery dissections: a review. J Emerg Med. 2016; 51: 508-518.

[5] Robertson JJ, Koyfman, A. Extracranial cervical artery dissections. Emerg Med Clin N Am. 2017; 35: 727-741.

[6] Morel A, Nagarra O, Touzé E, et al. Mechanism of ischemic infarct in spontaneous cervical artery dissection. Stroke 2012;43: 1354-1361.

[7] The CADISS trial Investigators. Antiplatelet treatment compared with anticoagulation treatment for cervical artery dissection (CADISS): a randomised trial. Lancet Neurol. 2015; 14: 361-367.

[8] Arnold M, Cumurciuc R, Stapf C, et al. Pain as the only symptom of cervical artery dissection. J Neurol Neurosurg Psychiatry 2006; 77: 1021-1024.

[9] Flumignan CD, Flumignan RL, Nakano LC, et al. Spontaneous carotid dissection. Rev Assoc Med Bras. 2017; 63: 397-400.

[10] Babik B, Peták F, Agócs S, et al. Diabetes mellitus: endothelial dysfunction and changes in hemostasis. [Diabetes mellitus: en- 
dotheldiszfunkció és haemostasiselváltozások.] Orv Hetil. 2018; 159: 1335-1345. [Hungarian]

[11] Debette S, Metso T, Pezzini A, et al. Association of vascular risk factors with cervical artery dissection and ischemic stroke in young adults. Circulation 2011; 123: 1537-1544.

[12] Pezzini A, Caso V, Zanferrari C, et al. Arterial hypertension as risk factor for spontaneous cervical artery dissection: a case-control study. J Neurol Neurosurg Psychiatry 2006; 77: 95-97.

[13] Arnold M, Pannier B, Chabriat H, et al. Vascular risk factors and morphometric data in cervical artery dissection: a case control study. J Neurol Neurosurg Psychiatry 2009; 80: 232-234.

[14] Vastagh I, Mészáros Zs, Szőcs I, et al. Characteristics of the etiology and risk factors of ischemic stroke occurring in young adults. [A fiatal életkorban bekövetkező ischaemiás stroke etiológiájának és rizikófaktorainak jellemzői.] Ideggyogy Szle. Procedings 2017; 2(3): 291. [Hungarian]

[15] Lucas C, Lecroart JL, Gautier C, et al. Impairment of endothelial function in patients with spontaneous cervical artery dissections: evidence for a general arterial wall disease. Cerebrovasc Dis. 2004; 17: 170-174.

[16] Völker W, Dittrich R, Greve S, et al. The outer arterial wall layers are primarily affected in spontaneous artery dissection. Neurology 2011; 76: 1463-1471.

[17] Ben Hassen W, Machet A, Edjlali-Goujon M, et al. Imaging of cervical artery dissection. Diagn Interv Imaging 2014; 95: 1151-1161.

[18] Nebelsieck J, Sengelhoff C, Nassenstein I, et al. Sensitivity of neurovascular ultrasound for the detection of spontaneous cervical artery dissection. J Clin Neurosci. 2009: 16: 79-82.

[19] Brott TG, Halerin JL, Abbara S, et al. 2011 ASA/ACCF/AHA/ AANN/AANS/ACR/ASNR/CNS/SAIP/SCAI/SIR/SNIS/ SVM/SVS guideline on the management of patients with extracranial carotid and vertebral artery disease. Circulation 2011; 124: e54-el30.
[20] Provenzale JM, Sarikaya B. Comparison of test performance characteristics of MRI, MR angiography, and CT angiography in the diagnosis of carotid and vertebral artery dissection: a review of the medical literature. Am J Roentgenol. 2009; 193: 11671174.

[21] Zinkstock SM, Vergouwen MD, Engelter ST, et al. Safety and functional outcome of thrombolysis in dissection-related ischemic stroke: a meta-analysis of individual patient data. Stroke 2011; 42: 2515-2520.

[22] Tsivgoulis G, Safouris A, Alexandrov V. Safety of intravenous thrombolysis for acute ischemic stroke in specific conditions. Expert Opin Drug Saf. 2015; 14: 845-864.

[23] Tsivgoulis G, Zand R, Katsanos AH, et al. Safety and outcomes of intravenous thrombolysis in dissection-related ischemic stroke: an international multicenter study and comprehensive metaanalysis of reported case series. J Neurol. 2015; 262: 2135-2143.

[24] Powers WJ, Rabinstein AA, Ackerson T. 2018 Guidelines for early management of patients with acute ischemic stroke: a guideline for healthcare professionals from the American Heart Association/American Stroke Association. Stroke 2018; 49: e46-ello.

[25] Várnai B, Simonyi G, Rapcsányi A, et al. The spontaneous recanalization of the internal carotid artery. [Az arteria carotis interna spontán rekanalizációja.] Orv Hetil. 2018; 159: 1525-1528. [Hungarian]

[26] Béjot Y, Daubail B, Debette S, et al. Incidence and outcome of cerebrovascular events related to cervical artery dissection: the Dijon stroke registry. Int J Stroke 2014; 9: 879-882.

(Forró Csilla dr., 540133 Marosvásárbely (Târgu Mureş), str. Secuilor Martiri 6B/7

Románia e-mail: csillaaforro@gmail.com)

\section{"Cupido atque ira pessimi consultores." (A vágy és a harag a legrosszabb tanácsadók.)}

A cikk a Creative Commons Attribution 4.0 International License (https://creativecommons.org/licenses/by/4.0/) feltételei szerint publikált Open Access közlemény, melynek szellemében a cikk bármilyen médiumban szabadon felhasználható, megosztható és újraközölhetö, feltéve, hogy az eredeti szerző és a közlés helye, illetve a CC License linkje és az esetlegesen végrehajtott módositások feltüntetésre kerülnek. (SID_1) 